\title{
HUBUNGAN INTENSI DENGAN PERILAKU KADER SEBAGAI PENOLONG PERTAMA SERANGAN STROKE
}

\author{
Imelda Feneranda Seravia Tambi ${ }^{1}$, Fidiana Kurniawati ${ }^{2}$, Irine Yunila Prastyawati ${ }^{3}$, \\ Nadia Oktiffany Putri ${ }^{4}$ \\ ${ }^{1}$ STIKES Dirgahayu Samarinda, ${ }^{2}$ STIKES RS. Baptis Kediri, \\ ${ }^{3}$ STIKES Katolik St. Vinsensius a Paulo, ${ }^{4}$ STIKES Panti Waluya Malang \\ Jl. Pasundan No.21, Jawa, Kec. Samarinda Ulu, Kota Samarinda, \\ Kalimantan Timur 75122 \\ e-mail: imelda.tambi90@gmail.com
}

\begin{abstract}
ABSTRAK
Pengurangan dan keterlambatan dalam mengambil keputusan akan mempengaruhi waktu pengobatan itu sendiri. Kader memiliki peran dalam melakukan tindakan pertolongan pertama pada pasien. Kader juga berperan dalam menyediakan beberapa layanan langsung seperti pertolongan pertama dan pemeriksaan tekanan darah. Tujuan penelitian ini adalah untuk menganalisis hubungan antara intensi dan prilaku kader sebagai penolong pertama serangan stroke. Jenis penelitian ini adalah study korelasi. Lokasi penelitian di Puskesmas Janti Kota Malang. Jumlah responden dalam penelitian ini adalah 44 orang kader kesehatan. Pengambilan sampel menggunakan simple random sampling. Pengumpulan data dilakukan dengan menggunakan kuesioner. Data dianalisis menggunakan non parametrik (spearman rho). Hasil menunjukkan bahwa ditemukan $\mathrm{p}=0,031$ atau $\mathrm{p}<0,05$, serta memilik $\mathrm{rs}+0.326$. Hasil analisis ini menunjukkan bahwa terdapat hubungan antara intensi dengan perilaku kader sebagai penolong pertama serangan stroke, hubungan ini memiliki kekuatan positif sedang. Ada hubungan antara intensi dengan perilaku kader sebagai penolong pertama serangan stroke. Peningkatan kinerja kader ditekankan dengan pemberian motivasi, dukungan dan pengakuan masyarakat untuk dapat meningkatkan intensi kader dalam menjalankan perannya sebagai penolong pertama serangan stroke.
\end{abstract}

Kata Kunci : Kader, Intensi, Perilaku, Penolong Pertama, Serangan Stroke

\section{PENDAHULUAN}

Identifikasi pasien stroke sedini mungkin sangat penting. Identifikasi ini dapat membantu meningkatkan manajemen pra rumah sakit dan ketepatan pengobatan (Jin et al., 2016). Pengurangan dan keterlambatan dalam mengambil keputusan akan mempengaruhi waktu pengobatan itu sendiri (Herlitz et al., 2010). Kecepatan dalam mengidentifikasi pasien dengan gejala serangan stroke dapat membantu menunjang manajemen pra rumah sakit dan pengobatan yang tepat (Jin et al., 2016). Menurut Donkor et al. (2014), banyak masyarakat yang tidak dapat mengenali salah satu faktor risiko stroke dan tanda peringatan stroke. Menurut Kim et al. (2011), kurangnya pemahaman terhadap pengenalan gejala stroke mengakibatkan keterlambatan pengobatan. Yang et al. (2014), mengemukakan bahwa sebagian besar masyarakat menunjukkan kemampuan yang buruk terhadap pengetahuan tanda peringatan stroke dan kesadaran untuk menanggapi gejala stroke tersebut. Data Dinas Kesehatan Kota Malang tahun 2017, menunjukkan bahwa penderita stroke terbanyak ditemui di wilayah kerja Puskesmas Janti yaitu berjumlah 379 jiwa. Penderita penyakit yang memiliki risiko antara lain diabetes melitus 1.895 jiwa dan hipertensi berjumlah 2.426 jiwa. Laporan data tersebutmemberikan gambaran bahwa pentingnya keterlibatan dan peran serta komunitas dalam mengidentifikasi risiko terjadinya serangan stroke serta penangannnya. 
Pertolongan pertama didefinisikan sebagai perilaku membantu dan melakukan perawatan awal yang diberikan untuk penyakit akut atau cedera. Pertolongan pertama dapat diprakarsai oleh siapa pun dalam berbagai situasi. Penolong pertama adalah seseorang yang terlatih dalam pertolongan pertama yang dapat mengenali, menilai, memprioritaskan kebutuhan pertolongan pertama, memberikan perawatan dengan menggunakan kompetensi yang sesuai, mengenali keterbatasan dan mencari perawatan tambahan bila diperlukan (Zideman et al., 2015).

Sasaran yang tepat dalam pelaksanaan upaya peningkatan tersebut adalah dengan melibatkan kader kesehatan. Kader dapat mengambil peran yang akurat dalam mengindetifikasi penyakit tidak menular yang terjadi di komunitas (Khetan et al., 2017). Kader memiliki peran dalam melakukan tindakan pertolongan pertama pada pasien. Pekerjaan kader berkaitan dengan sistem perawatan kesehatan setempat. Kader memberikan pendidikan dan informasi kesehatan sesuai dengan budaya suatu tempat. Kader membantu masyarakat menerima perawatan yang mereka butuhkan, memberikan konseling, bimbingan informal tentang perilaku kesehatan, advokasi kebutuhan individu dan kesehatan masyarakat. Kader juga berperan dalam menyediakan beberapa layanan langsung seperti pertolongan pertama dan pemeriksaan tekanan darah (Goodwin \& Laura, 2008).

Peningkatan perilaku dapat dipengaruhi oleh pengetahuan, sikap dan kontrol perilaku yang baik terhadap perilaku. Theory of planned behavior menunjukkan bahwa perilaku seseorang ditentukan oleh intensi untuk melakukan perilaku tertentu (Imm et al., 2011). International Federation of Red Cross and Red Crescent Societies (2016), mengungkapkan bahwa theory of planned behavior merupakan sebuah teori kunci dalam penerapan pertolongan pertama. Individu cenderung tidak membantu atau tidak bisa mengidentifikasi seseorang yang tidak mereka kenal. Alasan memberikan pertolongan pertama didasarkan pada bentuk tanggung jawab atau kebutuhan untuk berperilaku sesuai dengan cara yang diterima secara sosial, yaitu jika orang lain tidak membantu, maka tidak harus ataupun tidak pantas untuk melakukannya. Theory of planned behavior menjabarkan bahwa intensi merupakan penentu utama sebuah perilaku. Tujuan penelitian ini adalah untuk menganalisis hubungan antara intensi dan prilaku kader sebagai penolong pertama serangan stroke.

\section{METODE}

Jenis penelitian ini adalah study korelasi. Lokasi penelitian di Puskesmas Janti Kota Malang. Jumlah responden dalam penelitian ini adalah 44 orang kader kesehatan. Kriteria inklusi adalah responden berusia dewasa $(25-55$ tahun), bersedia menjadi responden, berkomitmen untuk mengikuti rangkaian proses penelitian, belum pernah mendapat pelatihan terkait stroke. Kriteria eksklusi meliputi responden dalam keadaan sakit, pernah mendapatkan pelatihan yang serupa. Pengambilan sampel menggunakan simple random sampling. Pengumpulan data dilakukan dengan menggunakan kuesioner. Kuesioner yang digunakan adalah dengan menggunakan skala likert 1 sampai dengan 7 (tidak setuju sampai dengan sangat setuju). Uji reliabilitas dan validitas telah dilakukan pada kuesioner ini. Data dianalisis menggunakan non parametrik (spearman rho). 


\section{HASIL DAN ANALISIS DATA}

Tabel 1 Karakteristik Responden

\begin{tabular}{|c|c|c|c|}
\hline No & Karakteristik & Jumlah & $\begin{array}{c}\text { Presentasi } \\
(\%)\end{array}$ \\
\hline \multirow[t]{2}{*}{1} & Jenis Kelamin & & \\
\hline & a. Perempuan & 44 & 100 \\
\hline \multirow[t]{4}{*}{2} & Umur & & \\
\hline & a. 25-35 tahun & 5 & 11 \\
\hline & b. $36-45$ tahun & 15 & 34 \\
\hline & c. $46-55$ tahun & 24 & 55 \\
\hline \multirow[t]{5}{*}{3} & Pendidikan & & \\
\hline & a. SMP & 20 & 45 \\
\hline & b. SMA & 19 & 43 \\
\hline & c. Perguruan & & \\
\hline & Tinggi & 5 & 11 \\
\hline \multirow[t]{4}{*}{4} & $\begin{array}{l}\text { Lama Menjadi } \\
\text { Kader }\end{array}$ & & \\
\hline & a. 1-5 tahun & 24 & 55 \\
\hline & b. $>5-10$ tahun & 2 & 5 \\
\hline & c. $>10$ tahun & 18 & 41 \\
\hline \multirow[t]{4}{*}{5} & Jenis Pekerjaan & & \\
\hline & $\begin{array}{l}\text { a. Tidak } \\
\text { Bekerja/IRT }\end{array}$ & 26 & 59 \\
\hline & b. Swasta & 5 & 11 \\
\hline & c. Wiraswasta & 13 & 30 \\
\hline
\end{tabular}

Karakteristik responden yang ditampilkan pada tabel 1 menunjukkan bahwa seluruh responden adalah perempuan (100\%). Kader di Puskesmas Janti Kota Malang terdiri dari perempuan dan laki-laki, tetapi didominasi oleh perempuan. Usia terbanyak pada penelitian ini terdapat pada rentang 46-55 tahun, kemudian 36-45 tahun dan 25-35 tahun. Karakteristik pendidikan menunjukkan bahwa sebagain besar kader kesehatan adalah lulusan sekolah menengah pertama sebanyak 21 responden. Berdasarkan masa kerja menjadi kader mayoritas berada pada rentang 1-5 tahun sebanyak 25 responden. Jenis pekerjaan terbanyak adalah ibu rumah tangga sejumlah 26 responden $(59 \%)$.
Tabel 2 Hasil Analisis Hubungan Intensi Dan Prilaku Kader Sebagai Penolong Pertama Serangan Stroke

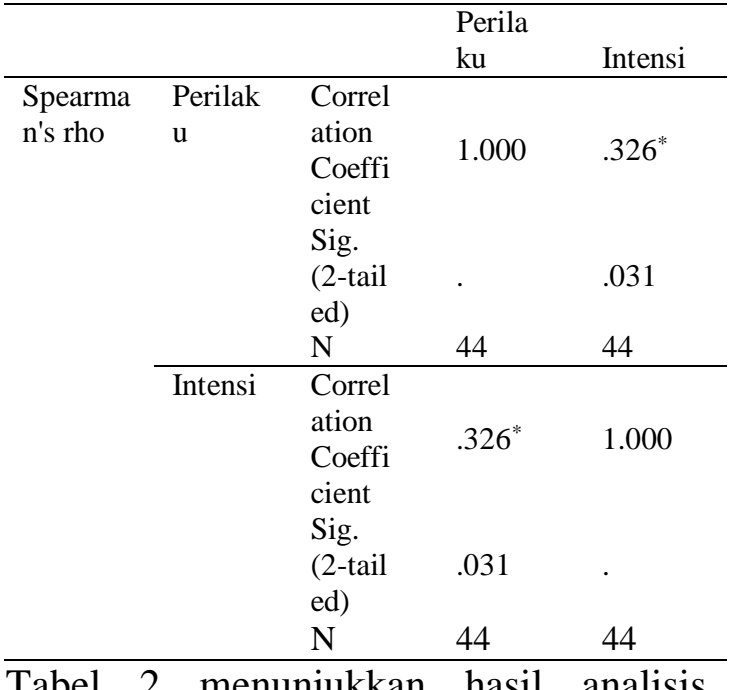

Tabel 2 menunjukkan hasil analisis korelasi dari Spearman Rho, ditemukan $\mathrm{p}$ $=0,031$ atau $\mathrm{p}<0,05$ maka $\mathrm{H}_{0}$ ditolak, serta memilik rs +0.326 . Hasil analisis ini menunjukkan bahwa terdapat hubungan antara intensi dengan perilaku kader sebagai penolong pertama serangan stroke, hubungan ini memiliki kekuatan positif sedang.

\section{PEMBAHASAN}

Hasil penelitian ini sejalan dengan Montano dan Kasprzyk (2008), mengungkapkan bahwa terdapat hubungan langsung antara intensi dengan perilaku. Hubungan ini menjelaskan bahwa intensi merupakan faktor terdekat dalam memprediksi perilaku individu. Theory of planned behavior menunjukkan bahwa perilaku seseorang ditentukan oleh intensi untuk melakukan perilaku tertentu (Imm et al., 2011). Skolarus et al. (2014) melakukan penelitian dengan menggunakan theory of planned behavior. Hasil penelitian menunjukkan bahwa prediksi perilaku yang paling cepat dan signifikan adalah intensi untuk melakukan perilaku. Misalnya, orang dengan intensi yang lebih tinggi untuk menelepon 911 lebih mungkin untuk benar-benar 
menelepon 911 ketika situasi stroke akut muncul.

Intensi dibentuk oleh sikap, norma subjektif dan kontrol perilaku. Ajzen (2005) mengungkapkan bahwa stabilitas intensi dapat terjadi jika terdapat jeda waktu antara pengukuran intensi dengan pengamatan tingkah laku. Menurut Ajzen (2005), intensi merupakan indikasi mengenai seberapa kuat keyakinan seseorang dalam melakukan sebuah perilaku. Intensi masih merupakan suatu keinginan atau rencana. Intensi merupakan faktor motivasi yang memiliki pengaruh pada sebuah perilaku. Seseorang dapat mengharapkan orang lain untuk melakukan sesuatu berdasarkan intensi. Faktor yang dapat mempengaruhi intensi antara lain adalah: kesesuaian antara intensi dan tingkah laku. Pengukuran intensi harus disesuaikan dengan perilakunya dalam hal konteks dan waktunya. Stabilitas intensi dapat terjadi jika terdapat jeda waktu antara pengukuran intensi dengan pengamatan tingkah laku. Setelah pengukuran intensi dapat ditemukan hal-hal yang dapat mengubah intensi seseorang. Intensi semakin besar berubah jika semakin panjang interval waktunya. Inkonsistensi Literal, faktor ini merupakan keadaan dimana individu tidak konsisten dalam menerapkan perilaku sesuai dengan intensi yang telah diungkapkan sebelumnya. Antisipasi hal ini dapat dilakukan dengan strategi implementasi intensi. Implementasi intensi dilakukan dengan meminta individu untuk merincikan bagaimana intensi itu dapat diimplementasikan dalam sebuah perilaku mencakup kapan, dimana dan bagaimana perilaku tersebut dapat dilakukan. Tingkat Dasar merupakan tingkatan kemungkinan sebuah perilaku diaplikasikan. Perilaku dengan tingkat dasar tinggi adalah perilaku yang diaplikasikan oleh hampir semua orang. Based rate rendah adalah tingkah laku yang hampir tidak pernah dilakukan oleh sebagian besar orang.
Intensi mengacu pada probabilitas subjektif individu yang terlibat dalam perilaku tertentu dan mencerminkan keinginan individu untuk mengadopsi perilaku tertentu (Ajzen, 2011). Intensi mengacu pada faktor-faktor motivasi yang mempengaruhi perilaku tertentu, semakin kuat niat untuk melakukan perilaku, semakin besar kemungkinan perilaku itu akan dilakukan. Setelah pengukuran intensi dapat ditemukan hal-hal yang dapat mengubah intensi seseorang. Intensi semakin besar berubah jika semakin panjang interval waktu pengukuran intensi tersebut. Terdapat kegiatan yang dapat meningkatkan implementasi intensi sebagai penolong pertama. Menurut Ajzen (2005), implementasi intensi dilakukan dengan meminta individu untuk merincikan bagaimana intensi itu diimplementasikan dalam sebuah perilaku. Perincian mencakup kapan, dimana dan bagaimana perilaku tersebut dapat dilakukan. Penyedia layanan kesehatan harus menekankan pentingnya menghubungi bantuan jika menemukan tanda dan gejala stroke daripada mencari perawatan di penyedia layanan, karena perilaku ini berkontribusi pada keterlambatan perawatan stroke pra-rumah sakit. Menurut International Federation of Red Cross and Red Crescent Societies (2016), pertolongan pertama pada serangan stroke yang utama mencakup mengenali tanda dan gejala awal stroke, memperhatikan waktu onset serta segera menghubungi EMS. Kader dapat berperan sebagai penolong pertama di komunitas. Peran kader menunjukkan secara jelas bahwa kehadiran kader bukan hanya untuk pencegahan penyakit, tetapi berkaitan dengan peran sebagai penolong pertama. Melalui peran sebagai penolong pertama, kader diharapkan dapat meningkatkan kesehatan di komunitas terkait dengan penanganan kasus gawat darurat.

Berkolaborasi dengan kader dapat meningkatkan kesehatan masyarakat. 
Salah satu peningkatan tersebut adalah dengan memberikan layanan perawatan kesehatan secara langsung, seperti pertolongan pertama dan melakukan pemeriksaan kesehatan. Menurut WHO (2010), kader dapat berperan dalam perawatan awal untuk menyelamatkan jiwa. Menurut Tuzzio (2018), kader berperan dalam penilaian kesehatan. Upaya yang diharapkan adalah melakukan penilaian klinis di dalam atau di luar kegiatan klinik. Menurut Jarvis et al. (2016), kader dapat memfasilitasi pemeriksaan dini, rujukan dan meningkatkan kepatuhan pengobatan dengan target individu di sekolah, lingkungan dan tempat-tempat keagamaan di masyarakat.

Sikap yang rendah dan negatif juga akan mempengaruhi intensi kader dalam melakukan pertolongan pertama serangan stroke. Kurangnya dukungan dari pihak terkait yang ditunjukkan oleh hasil variabel norma subjektif semakin menurunkan intensi kader dalam menjalankan perannya. Kontrol perilaku yang rendah dapat mengakibatkan ketidakmampuan kader mengenali kekuatan untuk mengatasi hambatan sebagai penolong pertama serangan stroke.

\section{KESIMPULAN DAN SARAN}

Terdapat hubungan antara intensi dengan perilaku kader sebagai penolong pertama serangan stroke. Peningkatan kinerja kader ditekankan dengan pemberian motivasi, dukungan dan pengakuan masyarakat untuk dapat meningkatkan intensi kader dalam menjalankan perannya sebagai penolong pertama serangan stroke. Kegiatan dilakukan dalam bentuk penghargaan secara berkala dan meyakinkan masyarakat melalui sosialisasi pentingnya peran kader dalam kasus kegawatdaruratan dalam komunitas. Pembentukan kader stroke sebagai upaya pengembangan program pos pelayanan terpadu (POSBINDU) dalam penanganan penyakit tidak menular dan program pengelolaan penyakit kronis (PROLANIS) di Puskesmas Janti dan instansi terkait lainnya.

\section{DAFTAR PUSTAKA}

Ajzen. (2005a). Attitutes, Personality and Behavior. Buckingham: Open University Press, Milton Keynes.

Ajzen, I. (2005b). Attitudes, Personality and Behaviour. Open University Press.

Donkor, E. S., Owolabi, M. O., Bampoh, P., Aspelund, T., \& Gudnason, V. (2014). Community awareness of stroke in Accra, Ghana. BMC Public Health, 14(1), 1-7. https://doi.org/10.1186/1471-2458-1 4-196

Goodwin, K. and, \& Laura Tobler. (2008). Community Health Workers Expanding $t$ The Scope of The Health Care Delivery System, (March 2007).

Herlitz, J., Wireklintsundstrom, B., Bang, A., Berglund, A., Svensson, L., \& Blomstrand, C. (2010). Early identification and delay to treatment in myocardial infarction and stroke: differences and similarities. Scandinavian Journal of Trauma, Resuscitation and Emergency Medicine, $18, \quad 48$. https://doi.org/10.1186/1757-7241-1 8-48

Imm, C. M., Holst, A., \& Iversen, J. M. (2011). An Application of a Revised Theory of Planned Behavior: Predicting the Intention to Use Personal Care Products without Endocrine Disrupting Chemicals. 
International Federation of Red Cross and Red Crescent Societies. (2016). International first aid and resuscitation guidelines 2016 for National Society first aid programme managers, scientific advisory groups, first aid instructors and first responders The.

Jarvis, J. D., Kataria, I., Murgor, M., \& Mbau, L. (2016). Community Health Workers: An Underappreciated Asset to Tackle NCD. Global Heart, 11(4), 455-457. https://doi.org/10.1016/j.gheart.2016 .10 .004

Jin, H. Q., Wang, J. C., Sun, Y. A., Lyu, P., Cui, W., Liu, Y. Y., ... Huang, Y. N. (2016). Prehospital identification of stroke subtypes in Chinese rural areas. Chinese Medical Journal, 129(9), 1041-1046. https://doi.org/10.4103/0366-6999.1 80521

Khetan, A. K., Purushothaman, R., Chami, T., Hejjaji, V., Madan Mohan, S. K., Josephson, R. A., \& Webel, A. R. (2017). The Effectiveness of Community Health Workers for CVD Prevention in LMIC. Global Heart, 12(3), 233-243.e6.

https://doi.org/10.1016/j.gheart.2016 .07 .001

Kim, H. J., Ahn, J. H., Kim, S. H., \&
Hong, E. S. (2011). Factors associated with prehospital delay for acute stroke in Ulsan, Korea. Journal of Emergency Medicine, 41(1), 59-63.

https://doi.org/10.1016/j.jemermed.2 010.04.001

Montaño, D. E., \& Kasprzyk, D. (2008). Theory of reasoned action, theory of planned behavior, and the integrated behavioral model. In Health Behavior and Health Education (pp. 67-96). San Francisco.

Tuzzio, L. (2018). Roles and Functions of Community Health Workers in Primary Care, 240-245.

Yang, J., Zheng, M., Cheng, S., Ou, S., Zhang, J., Wang, N., ... Wang, J. (2014). Knowledge of stroke symptoms and treatment among community residents in Western Urban China. Journal of Stroke and Cerebrovascular Diseases, 23(5), 1216-1224.

https://doi.org/10.1016/j.jstrokecere brovasdis.2013.10.019

Zideman, D. A., Singletary, E. M., Buck, E. D. J. De, Chang, W., Jensen, J. L., Swain, J. M., ... Markenson, D. S. (2015). Part 9: First aid 2015 International Consensus on First Aid Science with Treatment Recommendations, 95. https://doi.org/10.1016/j.resuscitatio n.2015.07.047 